\title{
RECOMMENDATIONS FOR IMPLEMENTING SUSTAINABILITY in New Product Development for Supply Chain Management
}

\author{
Lynn Fish
}

Lynn Fish, Ph.D.

Associate Professor of Management

Wehle School of Business

Canisius College. 2001 Main St., Buffalo, NY 14208.

Email: fishl@canisius.edu. Telephone: (716) 888-2642.

\begin{abstract}
Six recommendations remain relevant to incorporate sustainability into New Product Development for Supply Chain Management. With respect to sustainability and the Triple Bottom Line, the current literature highlights economic sustainability issues, with a growing wealth of knowledge in the environmental area, and a significant lack of research in social sustainability for New Product Development-Supply Chain Management. Research continues to highlight the importance of evaluating the end customers' sustainability requirements and what the end customer is willing
\end{abstract}


to pay for with respect to sustainability. Areas for future research are highlighted.

Keywords: Sustainability, New Product Development, Supply Chain Management

\section{LITERATURE REVIEW}

A thorough literature review of the New Product Development (NPD) process as it is coupled with Supply Chain Management (SCM) and transitioned through the quality, lean, time reduction and globalization movements highlight six critical recommendations that positively impact upon a successful product (Authors, 2002, 2003, 2008; Author, 2015 a,b). As the sustainability trend continues to add complexity to the NPD process, these six recommendations remain as critical advice to today's managers. Why address sustainability in NPD-SCM? NPD is the processes from design and development through sourcing and production planning. Without new products or service, companies will eventually cease to exist. SCM is the integration of processes that procure materials, transform them into intermediate and final products and deliver them to the end customer. In today's competitive environment, competition is supplychain versus supply-chain, and companies must integrate NPD with SCM to survive (Simchi-Levi et al., 2013). Carefully matching product characteristics to the appropriate supply chain strategy is critical to being competitive (Fisher, 1997), and product characteristics must be aligned with end customer requirements (Aitken, Childerhouse \& Towill, 2003).

Sustainability is a conceptual framework for aligning economic, environmental and social dimensions - also known as, the 'triple bottom line' (Asby, Leat \& Hudson-Smith, 2012) or 'people, planet, profits'. Without economic sustainability, which refers to the profitability aspect of any product, businesses will cease to exist, and thus, at a minimum, is an order qualifier for any product. Environmental sustainability, which refers to the 'green' aspects, includes the impact the product and its 
associated processes have on the environment in such areas as global warming and pollution. The key with environmental sustainability is for the natural resource consumption to be below the natural reproduction for products and processes. Since industrial activities in the United States account for about a third of carbon dioxide emissions and $40 \%$ occur due to transportation, supply chain activities are a primary factor in environmental sustainability (Gupta \& Palsule-Desai, 2011). In recent years, research in environmental sustainability has increased significantly. The third element of sustainability - the social aspect is the least researched (Gmelin \& Seuring, 2014a, Mu et al., 2011; Beske et al., 2014). Social sustainability can be divided into internal (the motivation, skills and loyalty of employees and supply chain business partners) and external (the value that is added to the community that the company operates in). While many businesses view the social aspect as less tangible and difficult to measure (Hutchins \& Sutherland, 2008), many people view these as trade-off's and not necessarily 'win-win' situations. For example, while environmental regulations provide social benefits, private costs for prevention and clean-up increase, which reduces competitiveness (Porter \& van der Linde, 1995).

Why address sustainability today? Today's business leaders are confronting resource depletion, responding to stakeholder demands (for example, shareholders, employees, environmental, government organizations and citizens) and recognizing new roles for businesses in economic and social change (CEOForumGroup, 2009). There is increasing pressure from government and society to address issues of global warming, raw material scarcity, and the deterioration of human rights (Seuring, 2004), consumer's concerns, legal requirements and company's intrinsic motivations (Beske et al., 2014). Today, roughly half of top executives view sustainability as a source of innovation and new business opportunity (Sroufe \& Melnyk, 201.

Sustainable Supply Chain Management (SSCM) can be defined as "the strategic, transparent integration and achievement of an organisation's 
social, environmental and economic goals in the systemic coordination of key inter-organisational business processes for improving the long term economic performance of the individual company and its supply chains" (Carter \& Rogers, 2008, p. 368). SSCM is the management of material, information and capital flows as well as the cooperation among companies along the supply chain, while addressing all three dimensions of sustainable development (economic, environmental and social) and are derived from customer and stakeholder requirements (Seuring \& Muller, 2008b). SSCM includes evaluation of the environmental impact, a multi-disciplinary perspective of the entire product life-cycle, and considerations for all stages of the entire product value chain (Gupta \& Palsule-Desai, 2011). Competitive advantages may be achieved through incorporating sustainability (Campbell, 2007).

Therefore, in order to remain competitive in today's marketplace, SSCM must be integrated with NPD. Doing so significantly increases the product design complexity (Gmelin \& Seuring, 2014a). However, incorporating sustainability decision-making in the NPD-SCM processes can significantly impact upon all sustainability aspects over the entire product life cycles. Unfortunately, as recently as 2010, there was little knowledge on why and how companies integrate environmental sustainability into NPD (Dangelico \& Pujari, 2010). Fortunately, research over the past 15 years has shown six key recommendations are paramount to new product success and remain relevant to incorporating sustainability into New Product Development (Author, 2015a, b): top management support and development of an integrated NPD-SCM strategy, resource allocation, financial support and support for a common, shared information system; a focus on marketing demands; supplier/customer integration; integrated physical networks, processes and information technology (IT) networks; a coordinated, cross-functional team; and a clear product vision. The intent of this article is to review the current state of sustainability - economic, environmental and social, with respect to these six recommendations and highlight various research areas that remain. The literature review focused on peer-reviewed articles in the decision sciences subject area. 


\section{Recommendation \#1: Top Management Support: Development of an Integrated Sustainable NPD-SSCM Strategy, Resource Allocation, Financial Support and Common, Shared Information System}

Top management support is one of the most critical aspects of developing NPD with SSCM (Gmelin \& Seuring, 2014a, 2014b; Griffin, 1997; Cooper, 2001; Marion et al., 2012) and includes strategy development, resource allocation, financial support and support for a common, shared information system. In general, the NPD process with sustainability is generally the same as traditional NPD; however, the underlying features and mechanisms needed to address the increased complexity require specific managerial skills and coordination (Driessen et al., 2013).

In general - and to meet economic or 'order qualifier' requirements for any product, top management develops the sustainable vision, mission, scope goals and explicit targets that direct NPD decisions towards sustainable products (Alblas, Peters \& Wortmann, 2014). In mature, sustainable NPD processes and organizations, sustainability scope and targets are clear and operational; customized tools, databases, design for sustainability methods, and supply chain tools exist; process definitions include sustainability issues; roles and responsibilities are clear; and NPD designers are experts in sustainability and are active in knowledge networks (Allen et al., 2012). It is imperative that top management develop a cohesive strategy (Alblas et al., 2014) that aligns the firm and its associated supply chains toward delivering sustainable products and services. Corporations that are beginning to address sustainability should focus on what sustainability means for their business and products through defining a sustainability strategy, scope, targets, and processes first, and worry less at the beginning about the metrics (Allen et al., 2012). A recent KPMG global survey showed that roughly two-thirds of companies have a corporate sustainability strategy with a quarter developing one (Sroufe \& Melnyk, 2013). Upper management needs to use different performance metrics for different types of NPD, particularly radical versus incremental product development (Driessen et al., 2013). 
Management must accept a certain amount of uncertainty in sustainable NPD, and encourage proactive capabilities through exploration, experimentation, double-loop learning, creativity and entrepreneurship (Allen et al., 2012). Top management drives process management through establishing processes with supply chain development partners that encourage design team competence and remove process issues (Gmelin \& Seuring, 2014a). Top Management needs to articulate that sustainability is critical to the company's future and important in all buyer-supplier relationships (and a 'shared focus') as well as proliferating resources to support sustainability efforts (Allen et al., 2012). For example, top management can create a management-level sustainability position and train employees and other supply chain member employees in sustainability, innovation and entrepreneurship. Similarly, top management can provide the resources and funds to establish a common, shared database, and although expensive, can reduce development costs, shorten time to market, improve consistency and data flexibility (Gmelin \& Seuring, 2014a). Additionally, to achieve economic goals, management needs to understand that the corporate reputation on green leadership may compensate for low financial and customer performance of green products (Driessen et al., 2013). Technology leadership reputation is directly related to green leadership as very green product innovations generally require advanced technology development (Seebode et al., 2012).

With respect to environmental sustainability, top management must align the strategic objectives of the firm with green initiatives (Gupta \& Palsule-Desai, 2011). Alignment may be accomplished through a green company policy (Driessen et al., 2013), which in the past has shown a significant impact upon green product innovation (Dangelico $\&$ Pujari, 2010). In the green company policy, top management conveys the company's commitment to sustainability through its values, norms and practices (Driessen et al., 2013). Top management should also use environmental benchmarking to guide their strategy development (Pujari, Peattie \& Wright, 2004). With respect to performance outcomes, use different performance metrics for 
green and non-green products (Driessen et al., 2013). It is recommended that management establish specific sustainability targets for energy efficiency, carbon dioxide footprint, product weight, materials (recyclables and recycling), sustainable packaging, and hazardous substances (Allen et al., 2012). As an example, IBM, a leader in balancing economic performance and environmental sustainability, embeds sustainability concepts in its NPD processes and its internal continuous improvement processes, aligns its business and sustainability strategy, integrates its operations and sustainability initiatives, maintains its sustainability culture, and develops systems that execute operational and sustainability goals (Peters et al., 2011).

While companies are starting to recognize the need to address social sustainability and the concept of social sustainability is growing (Vachon \& Mao, 2008), social sustainability issues are difficult to incorporate into NPD-SSCM as they are difficult to measure and results may be intangible. By addressing the social sustainability issues in the corporate sustainability policy and training NPD designers throughout the supply chain in social sustainability (Allen et al, 2012; Nawrocka et al., 2009), top management positively encourages designers to incorporate social sustainability issues in their decision-making. Additional top management encourages social sustainability through improving supply chain transparency and encouraging fair trade practices (Vacho \& Mao, 2008). For example, Walmart pledged to broaden its sustainability efforts to all functions within the company, to all parts of the world where it does business, and to work with suppliers (for example, Unilever and Proctor $\&$ Gamble) and with non-governmental organizations (for example, the China Green Foundation) (Anonymous, 2009, April 13).

In general, top management needs to foster a sustainability culture that creates an innovative, collaborative, integrative supply chain lead by a systems view of NPD-SSCM through resource and financial support through a common, shared information system. Without top management support, the new product is doomed to failure. Unfortunately, due to 
differences between global markets, industries, and cultures, research into this is more complex as factors will certainly interact. Some potential research streams for this recommendation include:

- Which company in the supply chain oversees and decides upon the final processes and product?

- How to resolve differences between sustainability visions and practices between partners?

- How to encourage a corporate and supply chain strategy to fully incorporate all three dimensions of sustainability into NPD?

- What level of financial and resource support are recommended to support NPD-SSCM?

- How to design an information system to encourage sustainability in NPD-SCM?

- How to manage global differences in sustainability perspectives and incorporation into NPD-SSCM?

- What performance metrics are recommended for environmental and social sustainability NPD? Do these differ between incremental and radical NPD (Driessen et al., 2013)?

\section{Recommendation \#2: Focus on Marketing Demands}

In today's customer-oriented environment where consumers are increasingly aware of environmental and social responsibility issues (Cohen et al., 2009), NPD-SSCM strategy needs to seamlessly incorporate critical market information into these processes and focus on the end customer (Gmelin \& Seuring, 2014a). Management needs to carefully analyze the end customers' sustainability requirements. A structured process bridges the gap between market planning and process management (Gmelin \& Seuring, 2014a). Some companies demonstrate their engagement in sustainability by seeking certifications such as ISO-14000 (for environmental standards) or following ISO-26000 (for social responsibility standards) (Gmelin \& Seuring, 2014b). As the sustainability trend continues, companies that lack certification or fewer then their competitors may 
trigger a loss of trust or a negative image to the customer (Gmelin \& Seuring, 2014b).

Consumer market strategies focus on bringing environmental and socially responsive products to market by concentrating on the key stages of the product life cycle (Cohen et al., 2009). Product Lifecycle Management (PLM) assesses the impact on the end customer as well as operational benefits such as cost reduction and risk management, and may increase revenues and market share (Cohen et al., 2009). PLM supports current best practices in NPD- SSCM including incorporating sustainability into NPD by evaluating product safety for the end-user, detecting marketing needs for ecological and social demands and restrictions, evaluating market changes to comply with company goals, resources and capabilities, and analyzing the market for sustainable needs and capabilities (Gmelin \& Seuring, 2014a). Designers need to balance the perceived trade-offs between product performance and sustainability (Luchs, Brower \& Chitturi, 2012). Strategist must also consider how much consumers are willing to pay to support sustainability efforts (Cohen et al., 2009). Unfortunately, until product sustainability is unequivocally positive for the end consumer, companies will struggle with sustainability efforts and marketing sustainable products (Luchs et al., 2012).

To encourage 'green' NPD, management recognizes that products' environmental impacts over their lifecycles can best be managed through goal-oriented and market-based mechanisms that provide flexibility (Gupta \& Palsule-Desai, 2011). While managers should implement procedures and rules that encourage green NPD, many companies struggle with reconciling greenness with costs (Driessen et al., 2013). Companies need to educate and convince customers to purchase its green products, which may cost more (Hassini et al., 2012). Marketing green new products is very complex due to several factors, such as product 'greenness' and industry factors. Important drivers of a successful product innovation strategy include the proposed marked orientation, associated processes to acquire information about customers and competitors, and research on 
sustainable NPD that includes information on non-market stakeholders (such as regulators or special interest groups) (Driessen et al., 2013). Strategies to introduce green NPD into the market are characterized by green targeting and green positioning. Green targeting, which is the degree to which a customer values green attributes, extends from niche to mass marketing; while green positioning, which is the degree to which green attributes are used to communicate to the market about how the product differs from existing products, may position green attributes at the core or not at all (Driessen et al., 2013). Greenness and industry type affect green targeting, and while green niches are emerging in some markets, market demand for green products in many industries is still low (Driessen et al., 2013).

Unfortunately, other than noting that marketing needs to detect, plan and manage for social sustainability, very little research on marketing and social sustainability for NPD-SCM exists (Gmelin \& Seuring, 2014a).

With respect to a focus on marketing demands, potential avenues for future research include:

- How to assess and address customer perceived trade-offs between the three sustainability dimensions?

- How to align the marketing strategy with the overall company and supply chain sustainability strategies?

- How to align the marketing strategy with specific product contextual attributes?

- How to assess social sustainability requirements in the end consumer market and align these with specific product contextual attributes?

- What is the relationship between green targeting and green positioning and product attributes?

\section{Recommendation \#3: Supplier/Customer Integration}

Sustainable supply chains differ from conventional supply chains with respect to the critical nature of selecting supply chain partners that 
match sustainability concerns (Beske et al., 2014). A critical challenge is to find suppliers that follow the same guiding principles with respect to sustainability as the company, and to extend this throughout the entire supply chain (Hutchins \& Sutherland, 2008; Allen et al., 2012). Joint sustainability initiatives emphasize supplier/buyer relationships in NPDSCM; however, many suppliers - particularly those further from the end customer, have little to no interest in sustainability (Allen et al., 2012). Successful sustainable product implementations depend upon suppliers' willingness to cooperate in this effort and to implement changes.

Supplier selection is critical to NPD-SSCM development and may include co-evolving, collaboration, and joint product and process development. Co-evolving evolves by improved relationships amongst members through activities that encourage joint growth in knowledge and partner development. Collaboration including both internal and external interactions is critical in sustainable NPD development (Tan \& Tracey, 2007). To support sustainability, supplier selection criteria includes a willingness to engage in sustainable practices (Wiskerke \& Roep, 2007), and technical superiority and cooperativeness (Ellram et al., 2007). Potential partners may demonstrate their commitment to sustainability through attaining environmental certifications (such as ISO14000) or following social sustainability standards (such as ISO26000) (Gmelin \& Seuring, 2014b) or being certified to SA8000 (Waage et al., 2005). (SA8000 is a standard that covers child labor, forced labor, health \& safety, right to collective bargaining, discrimination, disciplinary procedures, working hours, and compensation, and requires a social management system prior to certification (Waage et al., 2005)). Significant challenges in developing these relationships arise due to a lack of trust, data management issues, interoperability and communication issues (Gmelin \& Seuring, 2014a). Best practices to improve the buyer-supplier relationship include jointly implementing a code of conduct focused on all aspects of sustainability, holding regular meetings for enhanced communication, joint participation in activities that develop trust, developing joint decision-making procedures, assisting partners to learn new methods and sustainability, 
and potentially, providing financial support (Beske et al., 2014). Economically, practitioners need to analyze all relationships within the supply chain and pay particular attention to monetary and non-monetary costs to implement NPD practices that may outweigh the benefits (Homburg \& Kuehnl, 2014).

Since roughly $60 \%$ of the product's cost may be attributed to purchased materials (Monczka et al., 2009) green purchasing can significantly impact upon sustainability efforts. Therefore, it is not surprising to find a significant amount of research in green purchasing exists (Driessen \& Hillebrand, 2012) as suppliers play a significant role in green innovations (Lee \& Kim, 2011). Within green purchasing research, specific issues addressed include cooperation and communication between supply chain members to achieve a proactive sustainability approach, risk management to identify environmental and social problems prior to public exposure, and total life cycle product analysis (Seuring \& Muller, 2008a).

The need for strong, collaborative, cooperative relationships between supply chain members toward developing environmental products and using innovative, environmental technologies in processes exists in several studies (Vachon \& Klassen, 2006; Vachon \& Mao, 2008; Nawrocka et al., 2009). To select and evaluate suppliers for sustainable practices, use specific environmental requirements and environmental audits (Nawrocka et al., 2009). Companies, such as IKEA, Sony, Ericsson and Volvo, established their own detailed environmental sustainability qualification schemes (Nawrocka et al., 2009). Managers should be cautious about environmental compliance in different countries as legislative compliance may carry different meanings (Nawrocka et al., 2009).

Life Cycle Analysis (LCA), a pro-active technique, emphasizes the physical substance flow and chemical changes and can analyze the 'global' aspects in environmental supply chain relationships (Beske et al., 2014). LCA is a comprehensive approach to addresses the environmental impact at every supply chain stage from raw material extraction through disposal and focuses on supply chain partnerships (Bras, 2009). Current 
research indicates a gap and need for more holistic, relational research in this area (Ashby et al., 2012). LCA looks at all phases of a product's life cycle (Gmelin \& Seuring, 2014b) and assumes a significant amount of detailed information on products and processes (Allen et al., 2012). Therefore, LCA is limited in early product design (Sousa \& Wallace, 2006) and provides limited guidance to immature NPD organizations due to methodological problems, lack of knowledge and data (Allen et al., 2012).

Evaluating partner's social sustainability can be difficult as many indicators are dependent upon the economic resources of the family (poverty, nutritional status, healthcare, life expectancy and living conditions). Social sustainability efforts may be encouraged through green purchasing efforts (Seuring \& Muller, 2008b), and as mentioned previously, by encouraging supply chain members to incorporate social sustainability efforts - such as ISO26000 or SA8000, in NPD-SCM. Purchasing managers may also use social sustainability indicators such as equity, healthcare, education, housing, security and population (UNDSD, 2001). They should also be expected to engage in fair trade practices; however, fair trade practices may result in higher prices for the end consumer, who may prove unwilling to pay extra to support this practice (Hassini et al., 2012). In the United States, partner selection measures may include the average wages versus the cost of living in the region, wage equity, gender and minority wage equity, healthcare benefits, philanthropic activities, educational initiatives and workforce job safety; however, many indicators are dependent upon the economic resources available to the family and difficult to incorporate into decision-making (Hutchins \& Sutherland, 2008). Companies may encourage decent working conditions at suppliers by providing training and expert knowledge (Nawrocka et al., 2009).

Potential research streams with respect to supplier/customer NPDSSCM integration include:

- How to resolve differences between sustainability visions and practices between partners?

- How to extend LCA to address NPD (Sousa \& Wallace, 2006)? 
- How to address the gap and need for more holistic, relationship research in LCA - particularly in NPD (Ashby et al. 2012)?

- What are the significant factors that encourage and discourage supplier-customer relationships toward developing sustainable new products?

- How to gather and disseminate relevant knowledge and data to encourage sustainable NPD (Allen et al, 2012)?

- What are the best practices to incorporate and monitor social sustainability (e.g. indices) for supplier-customer interaction (Nawrocka et al., 2012)?

- How should managers extend sustainability efforts up the supply chain (Allen et al., 2012)?

- What measures should be used to select partners that foster sustainability in NPD?

\section{Recommendation\#4: Integrated Networks (Physical Network, Processes \& IT Management)}

As previously discussed, integrated supplier-customer relationships are critical to successful NPD-SSCM. Related to this are decisions which impact upon the development of this integrated network, from a physical network, process integration, and IT management perspectives. For example, decisions on how to technically and logistically integrate supply chain partners, the quality of information integration and exchange, and the operational processes used to integrate partners can impact upon the success of NPD in a supply chain (Beske et al., 2014). Formalized, streamlined processes between supply chain members support doing the NPD correctly (Marion et al., 2012).

The physical network design for sustainable new products includes decisions on location and transportation. However, there is a definitive link between product characteristics and supply chain structure (Fine, 1998), and channel structure plays a critical role in product success (Ellram et al., 2007). Innovative products are best delivered through responsive supply chains, while functional products are better served 
through efficient supply chains (Fisher, 1997). By continuing to use this product/process approach, managers can avoid un-necessary steps that do not support sustainability efforts (Gmelin \& Seuring, 2014a).

Best practices to develop streamline processes and coordination across globally-dispersed companies include product data management, process improvement management and engineering project management that extend across departments, companies and international borders (Gmelin \& Seuring, 2014a). Product data management enables data acquisition on environmental and social sourcing (Gmelin \& Seuring, 2014a). Companies that are more mature when it comes to sustainability use structured process management to guide projects, align targets and management sustainability targets (Allen et al., 2012). In strong collaborative relationships, data management is defined and controlled jointly (Gmelin \& Seuring, 2014a). Recommendations call for a common product development platform that balances economic product development with environmental and social sustainability along with project and program goals (Gmelin \& Seuring, 2014a). As previously discussed, PLM is a technique that may assist in the required information integration through all product phases including NPD to every supply chain member (Sudarsan et al., 2005). Relevant to this recommendation for integrated networks, PLM assists in reducing product data inconsistencies and improves coordination and control (Cantemessa et al., 2012) as information on revenues, costs, time, energy and materials may be exchanged across and within organizations (Gmelin \& Seuring, 2014b). Sustainable NPD success factors supported by PLM include process formalization (including product-focused sustainable data handling processes, process flexibility improvement, common change management processes for economic and environmental success, and workflow management for economic process execution) and cross-functional work (including cross-company and cross-functional sustainable process alignment) (Gmelin \& Seuring, 2014a). 


\section{The BRC Academy Journal of Business Vol. 6, No. 1}

With respect to IT management, recommendations call for a central location for data management and storage, which reduces data duplication and data inconsistencies (Gmelin \& Seuring, 2014a). Security concerns across informational boundaries increase with SCM; however, through utilizing procedures previously discussed to improve collaboration and encourage trust-building, concerns may be alleviated.

Environmental sustainability and integrated networks are related. For example, from a NPD and supply chain perspective, as product complexity increases with a larger number of target components, the value of short lead times increases and the environmental impact due to shorter distances decreases (Ferrer \& Ketzenberg, 2004). Similarly, partners located physically closer to the end customer are more likely to be aware of environmental issues (Nawrocka et al, 2009). As previously mentioned, partners are encouraged to manage physical network aspects through an environmental management system (Nawrocka et al, 2009).

Similar to other recommendations, no specific research was uncovered specifically related to social sustainability and this recommendation whether related to a physical network, processes or IT. Therefore, any research that explores the relationships between social sustainability and the processes/practices, physical network and IT will be beneficial. Additionally, within integrated networks, potential avenues for research include:

- What are the relationships between product complexity, lead time and environmental impact (Ferrer \& Ketzenberg, 2004)?

- What data management practices and characteristics should a product development platform have to encourage information exchange in PLM?

- What is the relationship between, and what factors impact upon, the channel structure, sustainability (all three areas) and NPD?

- What is the relationship between efficient and responsible supply chains, and the three areas of sustainability - economic, environmental and social? 


\section{Recommendation \#5: Coordinated, Cross-functional Team}

Departmental cross-functional collaboration is a success factor for sustainability in NPD (Petala et al., 2010). As noted previously, top management must support cross-functional NPD work (Marion et al., 2012). In today's business environment, cross-functional development may include internal organizational integration as well as inter-firm (external) collaboration (Homburg \& Kuehnl, 2014). Engineering collaboration across company boundaries is essential to developing innovative, sustainable products. As a first step towards collaboration, companies need to remove functional silos and adopt a product/process approach (Lambert et al., 1998). Collaboration improves through sharing information that focuses on the organization's common goals, sharing resources, improving communication, creating knowledge, trusting and making joint decisions (Beske et al., 2014), and it is dependent upon technology and organized processes (Johnson et al, 2010). Cross-functional teams reflect the core values of sustainable NPD (Sarin \& McDermott, 2003). To facilitate collaboration, the development team needs well-defined roles and functions (Zhang, 2011), and include experts with sustainability capabilities (Gmelin \& Seuring, 2014a). Specific to sustainability, the team should use a resourcebased view that reviews the inter-firm resources that are valuable for increased competitiveness (Gmelin \& Seuring, 2014a).

The coordination between environment, R\&D and purchasing departments significantly influences product improvement activities, particularly with respect to the environmental supply chain, and is an important feature of environmental supply chain cooperation (Green, Morton \& New, 1998). PLM supports NPD success factors related to teams including cross-functional and cross-company environmental and social data provisioning, avoiding silo thinking - particularly one solely focused on economic development, and managing key sustainability resources (Gmelin \& Seuring, 2014a).

Sustainable innovation is founded upon a sustainable culture in the firm and supply chain that encourages every employee to participate on 
a daily basis in sustainability efforts. Cross-functional, coordinated teams build upon this culture toward sustainable products and sustainable supply chain processes.

In today's business environment, coordinated, cross-functional teams, operating within and across cultural and global boundaries to develop NPD in supply chains, are expected. While the review here is not comprehensive, the available literature with respect to coordinated, cross-functional teams highlights sustainability in general, and does not address specific environmental or social sustainability issues in NPD-SCM. Addressing cultural, global issues and different perspectives with respect to sustainability are areas ripe for research.

\section{Recommendation \#6: A Clear Product Vision}

As with any NPD in order to be competitive, the product and its associated supply chain must match market requirements and value stream objectives (Fisher, 1997). Designers must understand the product definitions and work with manufacturing to develop a seamless product delivery process. As previously mentioned to encourage sustainability in NPD, top management needs to provide specific sustainability scope and targets, and educate and encourage NPD designers in sustainability. Designers must have clearly defined roles and responsibilities, build active knowledge networks, and must be capable of using customized tools, databases, and design for sustainability methods and tools.

From an economic standpoint, designers need to monitor NPD and costs through all NPD phases and realize that as more information is gathered, it is easier to estimate NPD costs (Chwastynk \& Kolosowski, 2014). Unfortunately, the gap between consumers articulated support of sustainability and actual sustainable consumption is very wide (UNEP, 2005), which implies that there is a minimum threshold of performance that sustainable products must meet (Luchs et al., 2012). In one case study, results show that customers tend to stick to conventional products instead of buying eco-products - even if price, quality and functionality are the 
same (Allen et al., 2012). Therefore, to promote sustainable products, it is important to improve consumer's confidence toward these products. Researchers continue to explore the perceived trade-off between product performance and sustainability, and results show that superior aesthetic design has a disproportionately positive effect on the likelihood of a successful sustainability-advantaged (versus performance-advantaged) product (Luchs et al, 2012). Therefore, a key recommendation for a company interested in sustainable products is to develop product aesthetic design capabilities (Luchs et al., 2012).

In recent years, green product innovation activities are growing (Driessen et al, 2013) as designers incorporate green into NPD through techniques such as Design for Environment (DfE), design-oriented work for green operations and green supply chain management (Sarkis et al., 2011; Seuring \& Muller, 2008a, b), and metrics focused on sustainability (Waage et al, 2005). The antecedents of product characteristics (greenness, relative advantage, costs and newness) and introduction characteristics (green targeting and green positioning) must be established and balanced (Driessen et al., 2013). NPD designers need to consider all supply chain management processes for all product lifecycle phases in the product's design including using environmentally-conscious methods in manufacturing, material selection, delivery to the end consumer and end-of-life product management (Gungor \& Gupta, 1999). Designers must consider green versus non-green characteristics for materials, energy and pollution across all supply chain processes (Dangelico \& Pontrandolfo, 2010). Unfortunately, many designers today are unfamiliar with the associated manufacturing processes, which create additional supply chain issues, and designers need guidance on aligning specific product contextual factors with an appropriate strategy (Ashby et al., 2012).

Designers need to develop a better understanding of the reverse value chain processes (reuse, repair, recycling, remanufacturing or redesign of returned products). For example, designers need to understand remanufacturing design concerns, such as product/component durability, level 
of product re-manufacturability, return stream processes, relationship between new and re-manufactured products, and consumer preferences between new and re-manufacturing products (Gupta \& Palsule-Desai, 2011). Design decisions on the timing and volume of product returns, remanufacturability, and specific component re-usability also exist (Gupta $\&$ Palsule-Desai, 2011). The reverse supply chain, product characteristics and strategy need to be appropriately aligned to encourage product success (Guide et al, 2006).

In recent years, Extended Producer Responsibility (EPR) policies shifted responsibility toward producers and away from local municipalities through incentives to incorporate environmental considerations into the design of products (Gupta \& Palsule-Desai, 2011). EPR examples include product take-back and recovery targets (such as home appliance recycling in Japan), disposal fees and material taxes (such as tire disposal in some U.S. states) and design/performance standards (such as U.S. fuel efficiency laws). Strategies to address EPR that impact upon NPD include: changing product design to incorporate end-of-life take back, disassembly and reuse; rationalizing parts and components to decrease material usage, eliminate hazardous substances, and facilitate remanufacturing; and choosing optimal product durability to include planned obsolescence, take-backs and replacements (Gupta \& Palsule-Desai, 2011).

While current research supports the recommendation for a clear, product vision in NPD-SSCM, research in the social sustainability arena is again lacking. However, research to integrate economic and NPD-SCM exist for over two decades. A potential avenue for economic research is to focus on the trade-offs and complex factors between end product and component performance and sustainability (Luchs et al., 2012). Similarly, research in NPD and environmental sustainability exists as well. Current questions within environmental sustainability to address include:

- How do carbon prices affect product line design decisions when different products require different capacities and have different 
levels of emissions during production (Gupta \& Palsule-Desai, 2011)?

- How do different regulatory regimes affect a firms' technology choice (Gupta \& Palsule-Desai, 2011)?

- What are the best practices to align DfE, product contextual factors and strategy alignment (Ashby et al., 2012)?

- How to address different global regulatory issues?

- How to address different technology choices for NPD-SSCM?

- How to balance emissions rights within a supply chain to optimize the value chain?

Within a clear product vision, research on the reverse supply chain alignment and sustainability is lacking. Potential research streams include:

- What is the relationship between specific product characteristics (contextual factors) and the reverse supply chain (Gupta \& PalsuleDesai, 2011)?

- With respect to specific components, which components should be reused in their original functionality, which components should be modified for re-use, and how many times should a particular component be reused (Gupta \& Palsule-Desai, 2011)?

\section{DISCUSSION}

The thorough, but not comprehensive, literature review reveals that the NPD-SCM recommendations (Authors, 2002, 2003, 2008; Author, 2015 a, b) continue to be relevant today in light of the increasing demand for sustainability in products and processes. These recommendations are not separate recommendations that may be implemented separately from one another; rather, they need to be integrated and jointly implemented in order to achieve a successful NPD. A single, specific NPD-SSCM strategy does not exist as managers must consider the specific product, industry and country factors relevant to their end market and supply chains in strategy development. 
Economic sustainability is paramount to any NPD-SCM development as products that do not meet the needs of the end customer will cease to be demanded and therefore, its supply chain will ultimately cease to exist. With respect to each recommendation, the discussion highlights key suggestions to develop new products and encourage overall sustainability development. However, as was highlighted at several points in the literature review (for example, Luchs et al, 2012), new products that do not meet the cost-value proposition of the end customer will fail. It is imperative that designers understand the trade-off between sustainability and performance as economic sustainability is an order qualifier for any new product. Methods, such as green targeting and green positioning, can assist to align the end market with financial and operational objectives of supply chains. Research in this area is still evolving.

Since Earth Day in 1970 in the U.S., efforts to incorporate environmental sustainability into decision-making increased. However, as noted in the literature review, research focused on incorporating environmental sustainability increased significantly in the past 5 years in NPD-SCM. PLM, DfE, and LCA are some of the techniques designers can use to address environmental concerns in NPD. Unfortunately, as noted previously, consumers do not fully understand the value of environmentally friendly products - nor are they ready to pay more for these attributes. So while designers struggle with incorporating and addressing environmental issues in product design, a significant hurdle is to bridge the gap between what consumers truly want from products with respect to the environment, and what they are willing to pay for.

Social sustainability research tends to focus on existing practices of firms with respect to treatment of their labor force, sourcing practices and community environmental impact. However, while corporate social responsibility has gained momentum in the past decade, as the literature review highlighted, research into social sustainability in NPD-SCM is extremely lacking. Current recommendations for NPD-SSCM development emphasize selecting and fostering relationships with similar socially 
sustainable values through trust-building and communication. Managers need to assist designers to overcome the complexity that is added by considering social sustainability issues in the product and process design through support, processes, and knowledge. It is critically important to understand the end customer's specific product requirements and what they are willing to pay for with respect to social sustainability. Management can encourage social sustainability in new products through leveraging their brand image to foster positive customer perceptions. Obviously there is a significant need for research specific to social sustainability in NPD-SCM.

\section{CONCLUSIONS}

Six recommendations are still relevant to incorporating sustainability into NPD for SCM. These six recommendations are: (1) Top management support to develop an integrated strategy support through resource and financial support through a common, shared information system is vital to developing a new product; (2) A focus on marketing demands; (3) Supplier/Customer integration; (4) Integrated networks (Physical Network, Processes \& IT Management); (5) Coordinated, cross-functional team; and (6) A clear product vision. In general, the underlying recommendation for NPD-SSCM is a focus on the end-customer. Research into economic sustainability in NPD-SCM is on-going as every product must be economically viable or it will disappear from the marketplace, environmental sustainability research is on the rise, but social sustainability research is extremely lacking. The issue for today's managers is to appropriately address environment and social sustainability issues through focusing on the end customer. Limitations to this research include the lack of specific data and test cases and difficulties in testing interactions due to the significant number of factors that may impact upon NPD-SSCM (such as industry, quality, cost, timing, and global issues). Fortunately, for researchers, potential research avenues in NPD-SSCM abound. 


\section{REFERENCES}

Aitken, J. Childerhouse, P. \& Towill, D. (2003). The impact of product life cycle on supply chain strategy. International fournal of Production Economics, 85, pp. 127-140. doi:10.1016/S0925-5273[03]00105-1

Alblas, A.A., Peters, K. \& Wortman, J.C. (2014). Fuzzy sustainability incentives in new product development: An empirical exploration of sustainability challenges in manufacturing companies. International Journal of Operations \& Production Management, 34(4), pp. 513-545. doi:10.1108/IJOPM-10-2012-0461

Allen, M.W., Walker, K.L.,\& Brady, R. (2012). Sustainability Discourse within a Supply Chain Relationship: Mapping Convergence and Divergence Journal of Business Communication. 49(3), pp. 210-236. doi:10.1177/0021943612446732

Anonymous (2009, April 13). Wal-Mart' earth month efforts circle the globe: Retailer unveils eco-friendly products, mobilizes workforce and engages global communities. PR Newswire. Retrieved from http://www.prnewswire.com/news-releases/wal-marts-earth-monthefforts-circle-the-globe-61799172.html.

Ashby, A., Leat, M. \& Hudson-Smith, M. (2012). Making connections: A review of supply chain management and sustainability literature. Supply Chain Management,17(5), pp. 497-516. doi:10.1108/13598541211258573

Barratt, M. (2004). Understanding the meaning of collaboration in the supply chain. Supply Chain Management: International fournal. 9(1), 30-42. doi:10.1108/13598540410517566

Beske, P., Land, A., \& Seuring, S. (2014). Sustainable supply chain management practices and dynamic capabilities in the food industry: A critical analysis of the literature. International fournal of Production Economics, 152, pp. 131-143. doi:10.1016/j.ijpe.2013.12.026

Bras, B. (2009). Sustainability and product life cycle management - issues and healthy emissions - a strategy for eco-effective product and system design. International fournal of Product Lifecycle Management, 4(1/2/3), 23-47. doi:10.1504/IJPLM.2009.031665 
Campbell, J. L. (2007). Why would corporations behave in socially responsible ways? An institutional theory of corporate social responsibility. Academic Management Review, 32(3), pp. 946-967. doi:10.5465/ AMR.2007.25275684

Cantamessa, M., Montagna, F.,\& Neirotti, P. (2012). Understanding the organizational impact of PLM systems: evidence from an aerospace company. International fournal of Operations \& Production Management, 32(2), 191-215. http://dx.doi.org/10.1108/01443571211 208623

Carter, C.R. \& Rogers, D.S. (2008). A framework for sustainable supply chain management: moving toward new theory. International fournal of Physical Distribution \& Logistics Management, 38, pp. 360-387. doi:10.1108/09600030810882816

CEOForumGroup (2009). Engaging external stakeholders: Sustainability performance. Retried from http://www.ceoforum.com.au/ article-detail.cfm?cid=8981\&t=/Rob-Hogarth-KPMG/Sustainabilityperformance/

Chwastyk, P. \& Kolosowski, M. (2014). Estimating the Cost of the New Product in Development Process. $24^{\text {th }}$ DAAAM International Symposium on Intelligent Manufacturing and Automation, 2013. Procedia Engineering, 69, pp. 351-360. http://dx.doi.org/10.1016/j. proeng.2014.02.243

Cohen, S., Wilkos, D., Garon, A, \& Gownder, J.P. (2009). Environmental and social responsibility in consumer product strategies: How central is environmental and social responsibility to your product? April 9, 2009. Accessed from Forrester Research, Inc. on Sept. 22, 2014 from https:// www.forrester.com/Environmental+And+Social+Responsibility+In+ Consumer+Product+Strategies/fulltext/-/E-RES53747

Cooper, A. C. (2001). Winning at New Products. Perseus Publishing, Cambridge, MA.

Dangelico, R.M. \& Pujari, D. (2010). Mainstreaming green production innovation: Why and how companies integrate environmental sustainability. Fournal of Business Ethics, 95(3), pp. 471-486. doi:10.1007/ s10551-010-0434-0 
Dangelico, R.M. \& Pontrandolfo, P. (2010). From green product definitions and classifications to the green options matrix. Fournal of Cleaner Production, 18(16-17), pp. 1608-1628. http://dx.doi.org/10.1016/j. jclepro.2010.07.007

Driessen, P.H., Hillebrand, B., Kok, R.A.W. \& Verhallen, T.M.M. (2013). Green New Product Development: The Pivotal Role of Product Greenness. IEEE Transactions on Engineering Management, 60(2), pp. 315-326. doi:10.1109/TEM.2013.2246792

Driessen, P.H., \& Hillebrand, B. (2012). Integrating multiple stakeholder issues in new product development: an exploration. fournal of Product Innovation Management, 30(2), 364-379. doi:10.1111/ j.1540-5885.2012.01004.x

Ellram, L.M., Tate, W.L. \& Carter, C.R. (2007). Product-process-supply chain: an integrative approach to three-dimensional concurrent engineering, International Fournal of Physical Distribution \& Logistics Management, 37(4), pp. 305-330. doi:10.1108/09600030710752523

Ferrer, G. \& Ketzenberg, M.E. (2004).Value of information in remanufacturing complex products. IIE Transactions, 36(3), pp. 265-277. doi:10.1080/07408170490274223

Fine, C. (1998). Clockspeed, Perseus Books, New York, NY.

Author (2015a). Sustainable Supply Chain Management \& New Product Development. Applications of Contemporary Management Approaches in Supply Chains. ISBN 978-953-51-4197-6, Croatia: InTech. 83-115.

Author. (2015b). New Product Development and Supply Chain Management: A Literature Review of the Past 15 Years. Proceedings of the North East Decisions Sciences Institute, Cambridge, MA, March 20-22, 2015.

Authors (2008). A Literature Review and Areas for Future Academic Research in New Product Development in Supply Chain Management. Proceedings of the Decision Sciences Institute Annual Meeting, Baltimore, MD, Nov. 2008, pp. 2291-6.

Authors (2003). New Product Development in Supply Chain Management: Recommendations for Practitioners and Future Academic Re- 
search. 2003 Northeast Decision Sciences Institute Conference, Providence, RI, March 2003, pp. 264-6.

Authors (2002). A Discussion of Managerial Issues in New Product Development for Supply Chain Management. 2002 International Conference on Industry, Engineering, and Management Systems Proceedings, Cocoa Beach, FL, March 13-15, 2002.

Fisher, M. (1997). What is the right supply chain for your product? Harvard Business Review, March/April, 105-116.

Gmelin, H. \& Seuring, S. (2014a). Achieving sustainable new product development by integrating product life-cycle management capabilities. International fournal of Production Economics, 154, pp. 166-177. doi:10.1016/j.ijpe.2014.04.023

Gmelin, H. \& Seuring, S. (2014b). Determinants of a sustainable new product development. Journal of Cleaner Production, 69, pp. 1-9. doi:10.1016/j.jclepro.2014.01.053

Green, K. Morton, BG. \& New, S. (1998). Green purchasing and supply policies: do they improve companies' environmental performance? Supply Chain Management, 3(2), pp. 89-95. doi:10.1108/13598549810215405

Griffin, A. (1997). PDMA research on new product development practices: updating trends and benchmarking best practices. fournal of Product Innovation Management, 14(6), 429-458. doi:10.1016/ S0737-6782(97)00061-1

Guide, V.D.R., Jr., Souza, G.C., van Wassenhove, L.N. \& Blackburn, J.D. (2006). The time value of commercial product returns. Management Science, 52(8), pp. 1200-1214. doi:10.1287/mnsc.1060.0522

Gungor, A. \& Gupta, S. (1999). Issues in environmentally conscious manufacturing and product recover: a survey. Computers and Industrial Engineering, 36(44), pp. 811-853. doi:10.1016/S0360-8352[106]00167-9

Gupta, S.\& Palsule-Desai, O.D. (2011). Sustainable supply chain management: Review and research opportunities. Indian Institute of Management Bangalore Management Review, 23, pp. 234-245.

Hassini, E., Surti, C. \& Searcy, C. (2012). A literature review and a case study of sustainable supply chains with a focus on metrics. 
International Journal of Production Economics, 140, 69-82. http://dx. doi.org/10.1016/j.ijpe.2012.01.042

Homburg, C., \& Kuehnl, C. (2014).Is the more always better? A comparative study of internal and external integration practices in new product and new service development. fournal of Business Research, 67, 1360-1367. http://dx.doi.org/10.1016/j.jbusres.2013.08.017.

Hutchins, M.J. \& Sutherland, J.W. (2008). An exploration of measure of social sustainability and their application to supply chain decisions. Journal of Cleaner Production, 16, pp, 1688-1698. doi:10.1016/ j.jclepro.2008.06.001

Johnson, M.E., Cochran, J.J., Cox, L.A., Keskinocak, P. Kharougeh, J.P., \& Smith, J.C. (2010). Product/service design collaboration. Managing the Product Life Cycle, pp. 1.

Lambert, D.M., Coooper, M.C., \& Pagh, J.D. (1998). Supply chain management: implementation issues and research opportunities. International fournal of Logistics Management, 9(2), 1-19. doi:10.1108/09574099810805807

Lee, K-H.,\& Kim, J-W. (2011). Integrating suppliers into green product innovation development: an empirical case study in the semiconductor industry. Business Strategy Environment, 20(8), 527-538. doi:10.1002/ bse.714

Luchs, M.G., Brower, J. \& Chitturi, R. (2012). Product choice and the importance of aesthetic design given the emotion-laden tradeoff between sustainability and functional performance. fournal of Product Innovation Management, 29(6), pp. 903-916. doi:10.1111/ j.1540-5885.2012.00970.x

Marion, T.J., Friar, J.H., \& Simpson, T.W. (2012). New product development practices and early-stage firms: two in-depth case studies. Fournal of Product Innovation Management, 29(4), 639-654. doi:10.1111/ j.1540-5885.2012.00930.x

Monczka, R.M., Handfield, R.B., Giunipero, L.C. \& Patterson, J.L. (2009). Purchasing and Supply Chain Management, Fourth Edition. SouthWestern Cengage, Mason, $\mathrm{OH}$. 
Mu, J., Zhang, G. \& MacLachlan, D.L., (2011). Social competency and new product development performance, IEEE Trans. Eng. Management, 58(2), 363-376. http://dx.doi.org/10.1109/TEM.2010.2099231

Nawrocka, D., Brorson, T. \& Lindhqvist, T. (2009). ISO14001 in environmental supply chain practices. Fournal of Cleaner Production, 17, pp. 1435-1443. doi:10.1016/j.jclepro.2009.05.004

Petala, E., Wever, R., Dutilh, C., \& Brezet, H.C. (2010). The role of new product development briefs in implementing sustainability: a case study. Journal of Engineering Technology Management, 27(3-4), 172-182. doi:10.1016/j.jengtecman.2010.06.004

Peters, A., Moore, C. \& Margarie, A. (2011). IBM's Approach To Sustainability Provides A Model For Long-Lasting Competitive Edge. Forrester Research. Accessed on Sept. 22, 2014 from https:// www.forrester.com/IBMs+Approach+To+Sustainability+Provides + A +Model+For+LongLasting+Competitive+Edge/fulltext/-/E-RES58152

Porter, M. \& van der Linde, C. (1995). Green and competitive: ending the stalemate. Harvard Business Review, 73(5), pp. 120-134.

Pujari, D., Peattie, K. \& Wright, G. (2004). Organizational antecedents of environmental responsiveness in industrial new product development. Industrial Marketing Management, 33(5), 381-391. doi:10.1016/ j.indmarman.2003.09.001

Sarin, S. \& McDermott, C. (2003). The effect of team leader characteristics on learning, knowledge application, and performance of crossfunctional new product development teams. Decision Science, 34 (4), 707-739. doi:10.1111/j.1540-5414.2003.02350.x

Sarkis, J., Zhu, Q. \& Lai, K. (2011). An organizational theoretic review of green supply chain management literature. International fournal of Production Economics, 130(1), pp.1-15. doi:10.1016/j.ijpe.2010.11.010

Seebode, D., Jeanrenaud, S. \& Bessant, J. (2012). Managing innovation for sustainability. R\&D Manage., 42(3), pp. 195-206.

Seuring, D. (2004). Industrial ecology, life cycles, supply chains - differences and interrelations. Business Strategy and the Environment, 3(5), pp. 306-319. doi:10.1002/bse.418 
Seuring, D. \& Muller, M. (2008a). Core issues in sustainable supply chain management: a Delphi study. Business Strategy and the Environment, 17, pp. 455-466. doi:10.1002/bse.607

Seuring, D. \& Muller, M. (2008b). From a literature review to a conceptual framework for sustainable supply chain management. Journal of Cleaner Production, 16(15), pp.1699-1710. doi:10.1016/ j.jclepro.2008.04.020

Simchi-Levi, D., Kaminsky, P. \& Simchi-Levi, E. (2013). Designing \& Managing the Supply Chain: Concepts, Strategies \& Case Studies, Third Edition, McGraw-Hill, Irwin, NY, NY.

Sousa, I. \& Wallace, D. (2006). Product classification to support approximate life-cycle assessment of design concepts. Technological Forecasting \& Social Change, 73, pp. 228-249. doi:10.1016/ j.techfore.2004.03.007

Sroufe, R.P. \& Melnyk, S.A. (2013). Developing Sustainable Supply Chains to Drive Value: Management Issues, Insights, Concepts and Tools. Business Expert Press. ISBN-13:978-1-60649-372-4.

Tan, C. L. \& Tracey, M. (2007). Collaborative new product development environments: Implications for supply chain management. Journal of Supply Chain Management, 43(3), 2-15. http://dx.doi.org/10.1111/ j.1745-493X.2007.00031.x

United Nations Environment Programme (UNEP) (2005). Talk the walk: Advancing sustainable lifestyles through marketing and communications. New York: UN Global Compact and Utopies.

UNDSD (United Nations Division for Sustainable Development) (2001). Indicators of sustainable development, guidelines and methodologies. http://sustainabledevelopment.un.org/content/documents/indisdmg2001.pdf. Accessed on 9/19/14.

Vachon, S., \& Klasen, R.D. (2006), Extending green practices across the supply chain: the impact of upstream and downstream integration. International fournal of Operations \& Production Management, 26(7), pp. 795-821. doi:10.1108/01443570610672248 
Vachon, S. \& Mao, Z. (2008). Linking supply chain strength to sustainable development: a country-level analysis. Journal of Cleaner Production, 16(15), pp. 1552-1560. doi:10.1016/j.jclepro.2008.04.012

Waage, S.A., Geiser, K. Irwin, F, Weissman, A.B., Bertolucci, M.D., Fisk, P. Basile, G., Cowan, S. , Cauley, H. \& McPherson, A. (2005). Fitting together the building blocks for sustainability: a revised model for integrating ecological, social and financial factors into business decision-making. Journal of Cleaner Production. 13, pp. 1145-1163. http://dx.doi.org/10.1016/j.jclepro.2004.06.003

Wiskerke, J. \& Roep, D. (2007). Constructing a sustainable pork supply chain: a case of techno-institutional innovation. Journal of Environment Policy Plan., 9(1), pp. 53-74. doi:10.1080/15239080701254982

Zhang, D.Z. (2011). Towards theory building in agile manufacturing strategies - case studies of an agility taxonomy. International fournal of Production Economics, 131(1), pp.303-312. doi:10.1016/ j.ijpe.2010.08.010

\section{Citation Information}

Fish, Lynn A. "Recommendations for Implementing Sustainability in New Product Development for Supply Chain Management." The BRC Academy Journal of Business 6, no. 1 (2015): 57-87. http://dx.doi.org/10.15239/ j.brcacadjb.2016.06.01.ja03 
